\title{
The Strategic Role of Sales Management for Market Access in the Pharmaceutical Sector
}

\author{
Lucrezia Maria de Cosmo \\ $\mathrm{PhD}$ in Business Economics and Management, Department of Economics, \\ Management and Business Law, University of Bari "Aldo Moro", Italy
}

Doi:10.19044/esj.2018.v14n34p146 URL:http://dx.doi.org/10.19044/esj.2018.v14n34p146

\begin{abstract}
In this paper we analyze the evolution of the role of the sales manager and of the sales force in a relational perspective of value creation in businessto-business contexts, included in the sale of prescription drugs, in Italy. The empirical research and the strategic implications are to highlight the importance of the customer-supplier relationship in business to business context and the role of the sales force in managing long-lasting relationships with customers. The work ends with the study of a task force model for easier market access by pharmaceutical companies and an expected value proposition through the sharing of knowledge and the creation of partnerships.
\end{abstract}

Keywords: Pharmaceutical Marketing, Relationship Marketing, Business to Business Marketing, Sales Management.

\section{Introduction and purpose of the research}

The pharmaceutical sector in Italy is experiencing moments of profound turbulence and competitive discontinuity never experienced in the past as a result of major environmental transformations including: the need for a reduction in health spending by the national and local health system, the difficulty of access to medical class and the contraction of productivity of the networks of scientific informants, the affirmation of generic drugs ${ }^{2}$ and the growing role of the local health system and its actors as a key customer ${ }^{3}$. Today, these phenomena force the pharmaceutical industry to review its marketing \& sales strategies for access to the increasingly restrictive drug market. In particular, the regionalistic reform of the national health system has led to an increase in access barriers for the product, forcing the pharmaceutical

\footnotetext{
${ }^{2}$ Introduced on the market through Law 425 of 8 August 1996, conversion of the D.L. 323 of 20 June 1996.

${ }^{3}$ For further information on the pharmaceutical sector, see also: Vallega, 1996; Brusoni, 1999; Smith, 2001; Frezza, 2005.
} 
company to consider a plurality of new interlocutors between decision makers and influencers; not just doctors ${ }^{4}$, but also pharmacists ${ }^{5}$ and technical, administrative, institutional and public figures (Data and Mariani, 2015). Therefore, in order for pharmaceutical companies to recover the profitability of past years, it is necessary, in particular, to differentiate the commercial approach and the contents of communication through a commercial organization that guarantees better access to the market of the drug (Market Access) and is based on a new structure able to consider as a client not only the medical profession but also all the actors that determine the development of the local health system through a consultancy relationship, based on a strong mutual trust and a high contribution in terms of problem solving, that goes beyond the scientific aspects and that embraces all the problems concerning the health and / or the profession of the doctor. To do this it is necessary to activate more and more decision-making processes that integrate people of different units - marketing and sales - into teams and structuring, making homogeneous and shareable the knowledge, that is information and managerial models (Drey and Pompini, 2005). All this can only be achieved through a transition, especially in the sales management, from a transactional approach (Kotler, 1976, Borden, 1964, Varaldo and Stanton, 1987) to a relational and therefore through an evolution of the role of sales manager and sales force. The first attempt of the company sees the birth of Key Account Manager (KAM) and Regional Account Manager (RAM). These figures, in the pharmaceutical sector, are destined to merge, in the very near future, under the direction of the Market Access Manager (Falotico and Mariani, 2014). In light of these brief introductory considerations, the present work, without having exhaustive pretenses for such a vast topic, aims to achieve the following objective: analysis of the evolution of the role of sales manager and sales force in a relational perspective of value creation in business-to-business contexts, mainly linked to the sale of prescription drugs, for the implementation of effective strategies of approach to Market Access (MA) by the pharmaceutical company.

\section{Theoretical background on the evolution of the role of Sales Management in a relational perspective of value creation}

The study of relationships with its customers is a long-standing topic in marketing literature, in particular with reference to the role that

\footnotetext{
${ }^{4}$ For prescription drugs, the decision to use, and therefore to consumption, revolves around the figure of the doctor who is the prevalent communication target of pharmaceutical marketing, in the case of self-medication drugs is the patient (Gianfrate, 2008).

${ }^{5}$ Pharmacists are now able to influence the sale of both self-medication and generic drugs by working, thanks to the high professional competence, a strong selection of brands at the entrance and adequate advice to the patient at the exit (Lugli.e Cristini, 2007).
} 
relationships play in improving competitive performance in the markets in which they are considered companies (Hakansson, 1982, Jackson, 1985; Gummesson, 1987, 1998 and 1999, Hakansson and Snehota, 1989, Morgan and Hunt, 1999, Vicari, Bertoli, Busacca, 2000). As is known, the relationship marketing deals with social, dyadic and network relations, deriving from processes of exchange of time, which foster relationships of cooperation and a real partnership between sellers and buyers siness especially in the business to business markets ( Anderson and Narus, 1984, Ferrero, 1992, Snehota and Tunisini, 1994, Gronroos, 1994, Castaldo, 1994). In business-to-business environments ${ }^{6}$, communication, through which the process of mutual adaptation takes place between purchasing and supplying companies, is the indispensable prerequisite for the continuity of long-term relationships (Fiocca, 2002). In particular, the personal and interactive dimension of BtoB communication constitutes the real big difference compared to any other type of business. The relational matrix literature emphasizes the contribution of sellers in the development of long-term relationships between the purchasing company and the seller with consequent increase in competitive advantage and company performance (William, Attaway, 1996, Marshall , Moncrief and Lassk 1999; Flaherty, Dahlstrom, Skinner, 1999, Palmatier RW et al., 2007, Sisti, Guenzi and Caiozzo, 2015). Empirical studies highlight the importance of interpersonal relationships between seller and buyer by demonstrating how the supplier's ability to create and maintain successful relationships with customers is completely dependent on the attitudes, skills and behaviors of their vendors (Langerak, 2001; Weitz and Bradford, 1999 ), which generate and increase the trust of the customer (Wilson, 1995) towards the supplier company as a whole (Doney and Cannon, 1997) positively influencing the satisfaction, the prospective fidelity (Liu, and Leach, 2001), the perceived quality, increasing the intention to repurchase and the desire to recommend the supplier to other potential customers (Foster and Cadogan, 2000). The seller is increasingly required to become "micro-marketing managers" (Lazzaro, 1995), to create value with and for customers (De Vincentis and Rackham, 1996), to develop with the latter a partnership relationship, to acquire skills for the proper management of the sales team, as well as the development of market analysis and planning skills (Wilson, 1993). In particular, it is affirmed the opportunity to reconfigure the commercial processes moving from an approach based on hard selling to one definable as smart selling (Sujan, Weitz and Kumar, 1994; Kohli, Shervani and Challagalla, 1998) in which sellers develop learning. and ability to adapt according to the specific characteristics of the interaction with the customer

\footnotetext{
${ }^{6}$ For a general study of the business to business markets, see also: Giulivi, 2001; Fiocca, Snehota and Tunisini, 2003, Foglio, 2014.
} 
considering the role of co-producers of the same (Jones et al., 2005). Furthermore, there is also a change in the activity of sales management, especially in the aspects concerning the selection and training of sellers, and in those concerning the evaluation and control systems (Weitz.and Bradford, 1999) as if the success of the sales, and therefore the improvement of company performance, depends on the seller is also true that this success is the result of the ability of the sales manager and the relationship between this and the sellers who make him head. In fact, sales management is an integral part of many performance models (Brown, \& Peterson, 1993; Churchill et al., 1985; Weitz, Sujian \& Sujian, 1986). In particular, Sales Management Effectiveness (achievable through the following antecedents: construction of close relationships with sellers, frequent work of the sales manager with the sales force, control of the same, good management of the relationship with the customer, motivation of sellers through remuneration) it is a source of competitive advantages and has a positive effect on the seller's commitement at the universal level and irrespective of the national culture (Murph and Li, 2012). Finally, sales managers are the link between the vision, the values of a company and the sales force (Wieseke et al., 2009). The greater the tendency of sales managers to assign to the sales force objectives of maintaining and developing the relationship with the current customer, the greater is the perspective of relational orientation of the company (Gronroos, 1990; Kalwani and Narayandas, 1995). On the basis of these assumptions, a construct of Commercial Orientation of the Company (Guenzi, 2000) was elaborated by Guenzi, which allowed to highlight the link between the relational activity carried out by the sales force and the set of factors able to significantly influence this activity: the complexity of the customers and the heterogeneity of their needs (from the external side), the complexity of the company's offer, the inter-functional coordination between marketing and sales (Kahn, 1996, 2001; Slater and Olson, 2000; al., 2001; Guenzi and Troilo, 2006) and the importance given to the sales force in acquiring competitive advantage (from the inside). On the one hand, this involves a profound change in the wealth of individual skills and competencies of sellers, a reformulation of the selection, training, incentive and control policies of the sales force and, on the other, a strategic rethinking in terms of the underlying commercial orientation. In recent decades, the need to systematically manage lasting relationships with customers, in highly dynamic and competitive contexts, has led to a revision and redesign of the logic and tools of customer management served through the creation of a new managerial model: the Key Account Management. The latter is a managerial philosophy (Ojasalo, 2001) which is characterized by its systematic nature, the high degree of coordination, interaction and transversality with respect to the various company functions, with the main objective of building strong relationships, long-lasting and above all profitable 
with a selected group of customers, giving them a specific term such as national account, global account (Shapiro and Posner, 1976), major account (Stevenson, 1980; Barret, 1986) and subsequently key account (Fiocca, 1982) or strategic account (Millman and Wilson 1995, Pardo et al. 1995, Guenzi 2002), offering them a special and personalized treatment (McDonald et al. 1997). Essential prerequisites for the success of this managerial model are: the sharing of intentions between customer and supplier that depends, in turn, on the stage of the relationship, the commitment of the management called to support the process, the implementation of a specific organizational structure and a company information system capable of ensuring integrated and coordinated customer management through effective and efficient sharing of knowledge (Sisti MA, 2004). The literature on relationship marketing, sales management and account management allow us to build a path of development for the management of the MA of the pharmaceutical company.

\section{Management of Market Access through Sales Management Effectiveness: results of an empirical study}

The management of pharmaceutical drug access to the market is of strategic importance if we consider that, according to some previous estimates provided by EFPIA ${ }^{7}$, Italy shows an average delay of 326 days, compared to other European countries, between the request for marketing authorization and access to the patient, considering both the hospital and the retail distribution. A more recent contribution estimates the time of access to medicines in Italy in the period 2015-2017 in 258 days (Lidonnici et al., 2018). This delay is the result of a rigorous control in the pricing and refund procedures of drugs by the AIFA (Italian Medicines Agency) as the only national body authorized to place medicines on the market. This input takes into consideration both the impact of the drug on the state budget, the comparison with the prices of other European countries and the cost-benefit ratio for the most innovative drugs. National marketing is not, therefore, necessarily equivalent to regional and local access, which is independently assigned by each decentralized authority with different methods and access difficulties. In the literature there is a recent work that analyzes the state of the pharmaceutical industry with respect to the issue of MA in Italy (Jommi, Otto, Armeni., De Luca, 2012). In particular, the results of this study highlight that the access of the drug to the market is mainly associated with a public business activity, which consists in the negotiation of prices and reimbursement of drugs, rather than a commercial activity in the sense side. The problem related to MA has led to organizational changes that have mainly affected the largest pharmaceutical companies with a prevalent retail activity. This change has resulted in the creation of an inter-functional

${ }^{7}$ EFPIA (Market Access Delays in http://www.efpia.org 03/12/2012). 
area of MA in which units from the marketing function and sales function are involved or in the creation of an autonomous MA unit with an added staff for this function and a director who assumes above all public business functions. Since the aim of the research work is to verify how much the new organizational structure contributed to the evolution of the role of sales in relational terms, it was decided to associate a qualitative analysis to a descriptive study (Mari, 1994; Yin, 2002) which finds justification in the coherence with the objective of study and with the multiform and complex nature of the phenomenon investigated. This analysis was conducted through an interview with a key informant within the company WINCH s.r.l. of Milan specialized in the provision of training services in the pharmaceutical field in Italy $^{8}$, with particular reference to the MA problem, and subsequently through the formulation of a case study made possible thanks to the valuable contribution of the Head of Public Affairs \& Market Access in Boehringer Ingelheim Italy (BIT).

The results of the interview with the key informant show how the pharmaceutical companies, through an organization of MA, have two fundamental objectives: 1. to know the minimum detail and at all levels (national, regional and local) the organization and the logic of the supply chain of subjects involved in the process of acquisition of a drug for hospital or widespread use; 2 . to create specialized operative units able to operate, alongside Marketing \& Sales, Medical and Regulatory, in order to facilitate the introduction of drugs into the national, regional and local health system. The majority of pharmaceutical companies have selected, for roles with different names (LAM - Local Access Manager, RAM - Regional Access Manager, KAM - Key Account Manager etc.), figures coming from the Sales Department, assigning their Job Descriptions and generic contact lenses with institutional or administrative figures of the Health System, often completely detached from the actual needs / opportunities of synergy with the other departments involved. It was therefore found that for the relational aspects, there is still work to be done on the creation of the composite operating teams (MA, Regulatory, Medical, Marketing, Sales) and the sharing of objectives, due to the presence of uncoordinated overlaps of activities on different targets by different subjects for a common goal. The situation in Boehringer Ingelheim Italy is different. The Group, based in Ingelheim, Germany, is one of the top twenty pharmaceutical companies in the world, and in 2017 recorded net sales of $€ 18.1$ billion. Within the group, Boehringer Ingelheim Italia (BIT) develops its business in the Milan, Reggello and Fornovo San Giovanni offices. The commercial sector is divided into three Divisions: Prescription and Hospital Medicines Division, Self-Grade and Wellness Products Division,

${ }^{8}$ (www.winch.it). 
Veterinary Division. With a net turnover of $€ 455$ million (+ $28 \%$ compared to the previous year), BIT is one of the top 20 pharmaceutical companies nationwide. In this reality, the MA is an activity that aims to ensure access to prescription drugs to patients who need it. This activity is based on two levers: producing not only clinical evidence, but also economic sustainability right from the pre-launch phases, that is those that precede the placing on the market (which coincides with the publication in the Official Journal), and the bringing these evidences to stakeholders direct and indirect decision makers, trying to meet the expectations not only of clinicians but also of national and regional payers, differentiating strategies for territories and classes of doctors through a MA plan that provides for the analysis of the different regional situations in terms of opportunities and barriers (starting from regional epidemiological data for an analysis of local scenarios) with the identification of action priorities. The diversification of strategies for classes of customers has as its sole effect the different declension of the message according to the interlocutor (General Manager, Health Director, Administrative Director, Pharmacologists, Patients Association, Policy Makers, etc.). The MA function is now included in the "Prescription Medicine" area, but for the Institutional part of Public Affairs it is functional in Staff with the General Management. It is composed of 5 Regional Affair Managers (RAM) ${ }^{9}$ and an institutional relations manager, a Health Economist \& Pricing Manager supported by a Pricing \& Reimbursement Manager and a relationship manager with AIFA, a regional Market Access supported by 4 project management managers and of relationships with patient associations and a structure of 16 Key Account Managers (KAM) ${ }^{10}$ plus two coordinators who deal with customers in the area. The fundamental requirement for the success of this organization is the transfer of knowledge and the consolidation of skills through rigorous training and assessment courses as well as a strong integration with the other departments of the company. The model of skills related to the human resources for the MA is structured as follows: technical-professional skills, managerial skills and transversal skills (organizational awareness, Problem Solving, Teamworking). The objectives achieved through the MA are: 1. the insertion of the drug in lists of various level and the speed of access in the same (for example the drug "Pradaxa" has been included in $90 \%$ of the regional list in less than a year) ; 2 . Drug-economy studies to encourage the appropriateness of pharmaceutical spending related to the company's

\footnotetext{
${ }^{9}$ The RAM deal with Policy Makers (Ministry, National Institutional Institutions, Regional Assessments, DG of AS), Institutional Stakeholders and Patient Associations.

${ }_{10}$ The KAM take care of the regional functional level (Healthcare General Directions, Regional Agencies, Pharmaceutical Departments ..) and Local (DG, DA, DS, Hospital Pharmacists, Clinical Pharmacologists, etc.). The Kam record the contacts in a CRM database whose interface is shared with the sales force.
} 
products; 3. Partnership with public subjects for the realization of projects (for example the project on organizational well-being with "Fiaso").

\section{An operational model of Market Access task forces and management implications}

The relational perspective of the sales force should not be experienced by the sales managers of pharmaceutical companies in a defensive way, but rather as an opportunity for strategic growth able, therefore, to bring potential benefits such as: increasing customer penetration, development of cross selling, the increase of the knowledge of the market through the acquisition of detailed information on customers, competitive distance. These benefits could be achieved through sales managers able to carry out internal sales team coordination activities able to create and transfer value to customers. From the data gathered from the interviews, the opportunity has emerged to create an operative model for the implementation of a MA task force by the pharmaceutical company that focuses on key technical and transversal skills ${ }^{11}$. The following figure shows, by way of example, a reference model for the Regional Market Access Manager.

Fig. 1: Regional Market Access Manager model

\begin{tabular}{|l|l|}
\hline ROLE & ACTIVITIES AND RESPONSABILITIES \\
\hline $\begin{array}{l}\text { Ensures the management of } \\
\text { activities to access the market of } \\
\text { new products and the prices to be } \\
\text { applied in the assigned territories, } \\
\text { in connection with local / regional } \\
\text { health authorities and scientific } \\
\text { associations }\end{array}$ & $\begin{array}{l}\text { It handles relationships with local health authorities and } \\
\text { scientific associations } \\
\text { It manages the relationship with the hospital management } \\
\text { and provides indications of drug-economy } \\
\text { Identify the Decision Makers } \\
\text { MTOR / PTO current situation of the company in relation to the } \\
\text { Coordinates the production of detailed plans } \\
\text { It supports the bidding process and the tender process by } \\
\text { developing appropriate proposals } \\
\text { It collaborates in the preparation of the PTOR files and } \\
\text { prepares / presents the PTO file } \\
\text { It supports the central functions, updating them on the } \\
\text { territorial dynamics of Market Access }\end{array}$ \\
\hline $\begin{array}{l}\text { MANAGERIAL / TRANSVERSAL SKILLS } \\
\text { SKILLS }\end{array}$ & \begin{tabular}{l} 
Relational \\
\hline
\end{tabular} \\
\hline
\end{tabular}

${ }^{11}$ Transversal skills, unlike technical / specialist skills, can be extended to all people and refer to knowing how to be and include a set of emotional, cognitive and social skills (Frasson D., 2011, page 39). ISFOL groups them into three macro-categories concerning the ability to diagnose, relate and deal with (Di Francesco G., 1998). 


\begin{tabular}{|c|c|c|}
\hline $\begin{array}{l}\text { Hospital-Territory organization } \\
\text { composition } \\
\text { Pharmaceutical market rules } \\
\text { Knowledge of local market } \\
\text { Pharmaco-economics } \\
\text { Business Analysis Project } \\
\text { Managem. } \\
\text { Skills on the subject of public } \\
\text { officials } \\
\text { Knowledge of purchase } \\
\text { procedures } \\
\text { Knowledge of stakeholders } \\
\text { involved in the dynamics of } \\
\text { Market Access }\end{array}$ & $\begin{array}{l}\text { Propensity to relationships } \\
\text { Negotiation } \\
\text { Responsibility } \\
\text { Influence } \\
\text { Situational leadership } \\
\text { Assertiveness } \\
\text { Teamworking } \\
\text { Partnerships }\end{array}$ & $\begin{array}{l}\text { Understanding needs } \\
\text { Focus results } \\
\text { Problem Solving / Decision } \\
\text { Making } \\
\text { Process management } \\
\text { Self confidence } \\
\text { Innovation guidelines }\end{array}$ \\
\hline
\end{tabular}

Through this operational model of MA task force implementation, the pharmaceutical company could have the opportunity to develop competitive advantages through the implementation of innovative partnership projects with healthcare companies and regional health institutions such as: 1 . Implementation of pathology networks and rationalization of PDTA ${ }^{12}$ for chronic diseases; 2 . Creation of functional aggregations in primary care; 3. Creation of communication areas for knowledge sharing in the specialist field (Scientific Social Network); 4. Implementation of drug-economy studies to encourage the appropriateness of pharmaceutical spending; 5. Dissemination of tele-assistance projects to make the most of the large sector of chronic diseases.

The critical success factor for the implementation of an effective Market Access task force, according to the operational model shown below, is the investment by pharmaceutical companies in human capital and in particular in life-long learning (Redding 1996). Previous studies have highlighted the complementarity between three main components of human capital: early ability, formal education and training (Ariga and Brunello, 2006; Arulampalam et al., 2004)). In particular, Scicchitano (2010) highlights how the strong relationship between heterogeneous human capital (education and job-training) and research and development $(R \& D)$ is important for innovation and economic growth as well as for the achievement of the strategy's main aims.

The research presents some limitations that need to be emphasized in order to stimulate further study of the work in the near future. First of all, the

12 The Diagnostic Therapeutic Care Paths are multi-professional and interdisciplinary assistance plans built for specific patient categories, prepared and used by healthcare providers, in order to improve the clinical results and the quality of the services offered to the customer, with a view to rationalization. of expenditure (Valentini I., Career Paths, Disease Management, GIt Diabetol Meteb, 27, 2007, pp. 65-68, in www.gidm.it/pdf/22007/Editoriale.pdf (24/09/2012). 
work has a descriptive and exploratory nature and takes into consideration only one case study. In particular, we could investigate the commercial orientation of pharmaceutical companies in order to verify the coherence between vision, values and objectives as well as verify the link between external and internal factors to the pharmaceutical company with the activities of the sales force also evaluating key competences. Finally, we could analyze the sales person equity (Fiocca, 2002) through a direct survey of the most important customers of pharmaceutical companies in order to verify the level of trust, satisfaction and prospective loyalty creating the conditions for a partnership and the maintenance of competitive advantages in the long term.

\section{References:}

1. Anderson J.C., Narus J.A. (1984), A Model of Distributor's Perspective of Distributor-Manufacturer Working Relationships, Journal of Marketing, Fall, 62-74.

2. Baldini A., Pacenti G.C., Salemme W. (2010), L'evoluzione della farmacia. Lo sviluppo di nuovi modelli organizzativi, Tecniche Nuove.

3. Bellman R. (1957), Dynamic Programming, Princeton University Press, Princeton.

4. Borden N., (1964), The Concept of the Marketing Mix, in Journal of Advertising Research, vol. 4, 2-7.

5. Brown S.P. \& Peterson R.A., (1993), Antecedents and consequences of salesperson job satisfaction: Meta - analysis and assessment of causal effects, Journal of Marketing Research, 30 (1), 63-77.

6. Bruschetta P., Ridella R., "Market access: uscire dalla comfort-zone", in www.Aboutpharma.com

7. Brusoni M., (1999), (a cura di), L’impresa Farmacia: gestione, marketing e sviluppo

8. del settore, Egea, Milano.

9. Castaldo S. (1994), Le relazioni distributive, Milano, Egea.

10. Churchill G.A. Jr., Ford N.M., Hartley S.W. \& Welker O.C. Jr., (1985), The determinants of salesperson performance. A metaanalysis, Journal of Marketing Research, 22 (2), 103 - 118.

11. Costabile M. (2001), Il Capitale relazionale, Mc Graw Hill, Milano, 73-74.

12. Cross J., Hartley S.W., Rudelius W. \& Vassey M.J. (2001), Sales force activities and marketing strategies in industrial firms: Relationships and implications, Journal of Personal Selling and Sales Management, 21 (3), 199-206.

13. Darmon R.Y., (1997), La Vente: Quelques Grandes Tendances Actuelles, Revue Francaise du Marketing, n. 164, 121-128. 
14. Data G., Mariani P. (2015), Market Access nel settore heathcare. Strategie, attori, attività e processi, Franco Angeli.

15. Demirken I., Demirken S. (2012), Network characteristics and patenting in biotechnology, 1990-2006, Journal of Management, n. 38, n. 6, 1892-1927.

16. Dewsnap B., \& Jobber D., (2002), A social psychological model of relations between marketing and sales, European Journal Marketing, 36 (7/8), 874-894.

17. De Vincentis J.R., Rackham N., (1998), Breadth of a salesman, The McKinsey Quarterly n. 4, 53-62.

18. Di Bernardo B., Rullani E. (1990), Il management e le macchine, Il Mulino, Bologna.

19. Doney P.M., Cannon J.P. (1997), An Examination of the Nature of Trust in Buyer-Seller Relationships, Journal of Marketing, Vol. 61, 3551.

20. Di Francesco G. (1998), Unità capitalizzabili e crediti formativi. Metodologie e strumenti di lavoro e i repertori sperimentali, ISFOL, Franco Angeli, Milano.

21. Drey A., Pompini M., Sales e marketing effectiveness per il settore farmaceutico, Guerini e Associati, 2005.

22. Falotico R., Mariani P. (2014), Le parole del Market Access: un'applicazione di Word Clouding, Tendenze Nuove n.1.

23. Ferrero G. (1992), Il marketing relazionale. L'approccio delle scuole nordiche, Trieste, LINT.

24. Fiocca R. (2002), La comunicazione nelle imprese business to business, Micro \& Macro Marketing, n. 2, 233-248.

25. Fiocca R., Snehota I., Tunisini A. (2003), Business Marketing, Mc Graw Hill, Milano.

26. Fisher R.J., Maltz E., \& Jaworski B.J., (1997), Enhancing communication between marketing and engineering: The moderating role of relative functional identification, Journal of Marketing, 61(3), 54-70.

27. Flaherty T.B., Dahlstrom R., Skinner S.J., (1999), Organizational Values and Role Stress as Determinants of Customer-Oriented Selling Performance, Journal of Personal Selling \& Sales Management, 19 (2), $1-18$.

28. Foglio A., (2014), Il marketing comunicativo business to business: la comunicazione offline e online dall'impresa alle imprese clienti. Franco Angeli.

29. Foster B.D., Cadogan J.W. (2000), Relationship selling and customer loyalty: an empirical investigation, Marketing Intelligence \& Planning, Vol. 18, n. 4, 185-199. 
30. Frasson D. (2011), Allenare le competenze trasversali, Franco Angeli, Milano.

31. Frezza L. (2005), Industria farmaceutica e management, Il sole 24 ore, Milano.

32. Galinat W.H., Muller G.F. (1988), Verbal responses to different bargaining strategies: a content analysis of real-life buyer-seller interaction, Journal of Applied Social Psychology, 18, 160-178.

33. Gianfrate F. (2008), Marketing farmaceutico. Peculiarità strategiche e operative, Tecniche Nuove, Milano.

34. Gianfrate F. (2009), Il parallel trade dei farmaci in Europa, Policy Paper I.com, 02/09, 1-36.

35. Giulivi G., (2001), Marketing relazionale e comunicazione business to business, Franco Angeli.

36. Grant R.M. (1991), The Resource-Based Theory of Competitive Advantage: Implication for Strategy Formulation, in California Management Review, Spring, (trad. it.), Analisi del Vantaggio Competitivo basato sulle Risorse, in Problemi di Gestione, vol. XIX, n.2, 1992.

37. Gronroos C., (1990), The Marketing Strategy Continuum: A Marketing Concept for the 1990s, Management Decision, Vol. 29, n.1, 7-13.

38. Gronroos C. (1994), Quo vadis Marketing? Towards a Relationship Marketing Paradigm, Journal of Marketing Management, 4, 347-360.

39. Guenzi P., (2000) Marketing relazionale e forza vendita: un'indagine empirica nel contesto italiano, Atti del Convegno "Le tendenze del marketing in Europa", Venezia 24 novembre, Università Ca Foscari.

40. Guenzi P. (2002), La Vendita Relazionale, Milano, Etas.

41. Guenzi P., Troilo G., (2006), Developing marketing capabilities for customer value creation through Marketing - Sales integration, Industrial Marketing Management, 35, 974-988.

42. Gummesson E. (1987), The new marketing - developing long-term interactive relationships, Longe Range Planning, Vol. 20, n.4, 10-20.

43. Gummesson E. (1998), Implemantation Requires a Relationship Marketing Paradigm, Journal of the Academy of Marketing Science, 26 Summer, 242-249.

44. Gummesson E. (1999), Total Relationship Marketing, Butterworth Heinemann, Oxford.

45. Hakansson H. (1982), International Marketing and Purchasing of Industrial Goods - An Interaction Approach, Chicester: Yohn Wiley \& Sons.

46. Hakansson H., (1987), Industrial Technological Development: a Network Approach, Croom Helm, London. 
47. Hakansson H., (1990), Technological Collaboration in Industrial Network, in European Journal of Marketing, September.

48. Hakansson H., Johansson J., 1992, A Model of Industrial Networks, in Axelsson B., Easton G., "Industrial Networks. A new view of reality", Routledge, London.

49. Hakansson H., Snehota I. (1989), No business is an island: the network concept of business strategy, Scandinavian Journal of Management, Vol. 5, n.3, 187-200.

50. Hakansson H., Snehota I. (1995), Developing Relationships in Business Nerworks, Routledge, London.

51. Hunt S.D. (1997), Competing Through Relationships: Graunding Relationnship Marketing in Recource-Advantage Theory, Journal of Marketing Management, Vol.13, 431-445.

52. Itami H. (1987), Mobilizing Invisible Assets, Harvard University Press, Boston.

53. Jackson B.B. (1985), Build customer relationship that last, Harvard Business Review, November-December, 120-128.

54. Jommi C., Otto M., Armeni P., De Luca C. (2012), Market access management by pharmaceutical companies in a complex environment: the Italian case study, Journal of Medical Markeitng, 2, 93-103.

55. Jones E., Brown S. P., Zoltners A.A., Weitz B.A. (2005), The changing environment of selling and sales management, Journal of Personal Selling \& Sales Management, vol. XXV, n. 2, 105-111.

56. Jones E., Stevens C., Chonko B. (2005), Selling ASAP: Art, Science, Agility, Performance, Cincinnati: Thomson Learning.

57. Kahn K.B., (1996), Interdepartmental integration: A definition with implications for product development performance, Journal of Product Innovation Management, 13, 137-151.

58. Kahn K.B., (2001), Market orientation, interdepartmental integration and product development performance, Journal of Product Innovation Management, 18, 314-323.

59. Kalwani M.U., Narayandas N., (1995), Long Term ManufacturerSupplier Relationships: Do They Pay Off for Supplier Firms, Journal of Marketing, vol. 59, n.1, 1-16.

60. Kohli A.K., Shervani T.A., Challagalla G.N. (1998), Learning and Performance Orientation of Salespeople: The Role of Supervisors, Journal of Marketing Research, vol. 35, 263-274.

61. Kotler P., (1976), Marketing Management, ISEDI, Milano.

62. Kotler P., Shalowitz J., Steven R., Turchetti G. (2010), Marketing per la Sanità, Mc Graw Hill, 6.

63. Langerak F. (2001), Effect of market orientation on the behaviors of salespersons and purchasers, channel relationships, and performance 
of manufacturers, International Journal of Research in Marketing, Vol. 18.

64. Lazzaro G. (1995), Professione venditore, Etas libri, Milano.

65. Lidonnici D., Ronco V., Isernia M., Lanati E., Jommi C., Canonico P.L., Genazzani A. (2018), Tempi di accesso ai farmaci in Italia nel periodo 2015-2017. Analisi delle tempistiche di valutazione dell'Agenzia Italiana del Farmaco, Global \& Regional Health Technology Assessment, 1-9.

66. Liebeskind J.P., Oliver A.L., Zucker L. (1996), Social networks, learning and flexibility, sourcing scientific knowledge in new biotechnology firms, Organization Science, vol. 7, 428-443.

67. Liu A.H., Leach M.P. (2001), Developing Loyal Customers with a Value adding Sales Force: examining Customer satisfaction and the Perceived Credibility of Consultative Salespeople, Journal of Personal Selling \& Sales Management, Vol. 21, n.2.

68. Lugli G., Cristini G., (2007), "La distribuzione dei farmaci”, in (a cura di) Lugli G. Marketing Channel - la creazione di valore nella distribuzione specializzata, Utet, Milano.

69. Mari C., (1994), Metodi qualitativi di ricerca. I casi aziendali, Torino: Giappichelli Editore.

70. Marshall G.W., Moncrief W.C., Lassk F.G. (1999), The Current State of Sales Force Activities, Industrial Marketing Management, vol.28, Jennuary, 87-98.

71. Mintzberg H. (1979), Patterns in strategy formation, Management Science, XXIV, 9, 934-948.

72. Morgan R.N., Hunt S.D. (1999), Relationship-Based Competitive Advantage: The Role of Relationship Marketing in Marketing Strategy, in Journal of Business Research, vol. 46.

73. Murphy W.H., Li N., (2012), A Multination study of sales manager effectiveness with global implications, Industrial Marketing Management, doi:10.1016/j.indmarman.2012.06.012.

74. Murray J.S. (1986), Understanding competing Theories of negotiation, Negotiation Journal, 2, 179-186.

75. Norman R., Ramirez R. (1995), Designing Interactive Strategy, Wiley, Chichester, (trad. it). Le strategie interattive d'impresa, Etas, Milano, 1995.

76. Palmatier R.W., Scheer L.K., Houston M.B., Evans K.R., Gopalakrishna S. (2007), Use of relationship marketing programs in building customer-salesperson and customer-firm relationships: Differential influences on financial outcomes, International Journal of Research in Marketing, 24, 210-223. 
77. Piacente G.C., Nadin G., Salemme W. (2011), La farmacia dei servizi - Opportunità e soluzioni nell'integrazione all'assistenza sanitaria, Tecniche Nuove, Milano.

78. Raimondi M. (2004), Editoriale Micro \& Macro Marketing, 2, 235.

79. Redding S (1996) Low-skill, low-quality trap: strategic complementarities between human capital and R\&D. Economic Journal Vol. 106, n. 435, 458-470

80. Ridella R. (2006), Strategie possibili per un marketing farmaceutico alla svolta, Strategie di Business n. 14 in www.atkearney.it

81. Rouziés D., Anderson E., Kohli A.K., Michaels R.E., Weitz B.A., \& Zoltners A.A., (2005), Sales and marketing integration: A Proposed framework, Journal of Personal Selling and Sales Management, 25 (2), 113-122.

82. Rummelt R.P. (1984), Towards a Strategic Theory $\backslash$ of the Firm, in R.L. Lamb (a cura di) "Competitive Strategic Management”, Prentice Hall, Englewood Cliffs, 557-570.

83. Signori P., Gaudenzi B., Russo I., Le nuove potenzialità del doppio posizionamento strategico, 9 International Conference Marketing Trends, Venice, january 21-23 2010.

84. Sisti M.A., Guenzi P., Caiozzo P., (2015), Gestire le vendite. L'eccellenza nel sales management, Egea S.p.a.

85. Slater S.F., \& Olsan E.M. (2000), Strategy type and performance: the influence of sales force management, Strategic Management Journal, 21(8), 813-830.

86. Smith M., (2001), Pharmaceutical Marketing, Pharmaceutical Product Press, NY, USA.

87. Snehota I., Tunisini A (1993)., Marketing relazionale: un paradigma diverso?, Economia e Politica Industriale, 81.

88. Sujan H., Weitz B.A., Kumar N., (1994), Learning Orientation, Working Smart, and Effective Selling, Journal of Marketing, vol. 58, 39-52.

89. Tracy L. (1995), Negotiation. An emergent process of living systems, Behavioural Science, 40, 41-55.

90. Trieste L. (2007), Farmacie e distribuzione: gli scenari future, Working paper Service, In-Sat Lab, Scuola Superiore Sant'Anna, 28 febbraio.

91. Valentini U., Percorsi Assistenziali. Disease Management, GIt Diabetol Meteb, 27, 2007, 65-68, in www.gidm.it/pdf/22007/Editoriale.pdf

92. Vallega S., (1996), Marketing per la salute. Strumenti e tecniche in azienda e in farmacia per i prodotti da automedicazione, Etas Libri, Milano. 
93. Varaldo R., Stanton W., (1987), Marketing, Il Mulino, Bologna.

94. Vicari S. (1991), L'impresa vivente, Milano, Etas.

95. Vicari S., Bertoli G., Busacca B. (2000), Il valore delle relazioni di mercato. Nuove prospettive nell'analisi delle performance aziendali, in Finanza, Marketing \& Produzione, vol. 18, 7-54.

96. Weitz B.A., Sujian H. \& Sujian M. (1986), Knowledge, motivation, and adaptive behavior: A framework for improving selling effectiveness, Journal of Marketing, 50 (4), 174-191.

97. Weitz B.A., Bradford K.D. (1999), Personall Selling and Sales Management: A Relationship Marketing Perspective, Journal of the Academy of Marketing Science, Vol. 27, 241-254.

98. Wernerfelt B. (1984), A Resource-based View of the Firm, in Strategic Management Journal, n.5.

99. Wieseke J., Ahearne M., Lam S.K., van Dick R., (2009), The role of leader in internal marketing, Journal of Marketing, 73 (2), 123-145.

100. Williams M.R., Attaway J.S. (1996), Exploring Salesperson's Customer Orientation as a Mediator of Organizational Culture's Influence on Buyer-Seller Relationships, Journal of Personal Selling \& Sales Management, 16 (4), 33-52.

101. Wilson D.T. (1995), An Integrated Model of Buyer - Seller Relationships, Journal of the Academy of Marketing Science, Springer.

102. Wilson K., (1993), Managing the industrial salesforce of the 1990s, Journal of Marketing Management vol. 9, 123-140.

103. Wrigt R.F., Lundstrom W.J., (2003), Physicians' perceptions of pharmaceutical sales representatives: A model for analysing the customer relationship, International Journal of Medical Marketing, vol. 4, 1, 29-38.

104. Yin R., (2002), Case Study Research, Applied Social Research Methods Series. 